\title{
Seasonal cycles in phytoplankton mycosporine-like amino acids and the attenuation of ultraviolet radiation in coastal surface waters in Sagami Bay
}

\author{
Satoru Taguchi ${ }^{1, *}$, Ken-IChi YamaO ${ }^{1,2}$, Yoshinori Yamada ${ }^{1,2}$, Jun-ICHi Hagimoto ${ }^{1,2}$, \\ Akira Takeuchi $^{1,2}$, Kionobu Chiba ${ }^{1,2}$, Tomoyo Katayama ${ }^{1}$, Shozo Motokawa ${ }^{1}$, \\ Ai Murata ${ }^{1} \&$ Hitomi TAirA ${ }^{1}$ \\ ${ }^{1}$ Laboratory of Biological Oceanography, Soka University, 1-236 Tangi-Cho, Hachioji, Tokyo 192-8577, Japan \\ ${ }^{2}$ Mailing address, 1238-1-306 Ishikawa-Cho, Hachioji, Tokyo 192-0032, Japan
}

Received 14 April 2016; Accepted 17 August 2016 Responsible Editor: Satoshi Nagai

\begin{abstract}
The concentration of mycosporine-like amino acids (MAAs) of phytoplankton and the attenuation coefficients of ultraviolet radiation (UVR) were determined in coastal surface waters in Sagami Bay during the period from 2004 to 2012 to examine the seasonal cycle. Four major MAAs, including mycosporine-glycine, palythine, shinorine, and porphyra-334, were detected throughout the year. Mycosporine-glycine was the most dominant type, reaching more than $100 \mathrm{nM}$, whereas porphyra-334 was the least dominant type, barely reaching $20 \mathrm{nM}$. The total concentration of the four MAAs was high in the high water temperature (WT) months (February-July) and low in the low WT months (August-January). The seasonal cycle was repeatedly sustained for six years. The attenuation of ultraviolet radiation at two wavelengths, 320 and $340 \mathrm{~nm}$, also followed a similar seasonal cycle: high in the warm period and low in the cool period. The attenuation of UVR at two wavelengths $\left(k_{\mathrm{d}}[320]\right.$ and $\left.k_{\mathrm{d}}[340]\right)$ was linearly correlated with the concentration of MAAs $(p<0.01)$. Solar energy was the environmental driving force responsible for the seasonal cycles of MAAs, which were further enhanced by increased biomass and nutrient availability. Individual groups in the phytoplankton community might share roles to protect the entire community from UVR in the marine ecosystem by producing various MAAs.
\end{abstract}

Key words: Chl $a$, mycosporine-glycine, palythine, PAR, porphyra-334, shinorine, UVR attenuation

\section{Introduction}

High levels of ultraviolet radiation (UVR) are environmentally stressful to phytoplankton (e.g. Helbling \& Zagarese 2003). An increase in solar UVR (from 280 to $400 \mathrm{~nm}$ ) and a high UVR proportion compared to total solar photosynthetically active radiation (PAR from 400 to $700 \mathrm{~nm}$ ) in addition to UVR is expected in coastal water ecosystems at mid-latitudes (e.g. Sugawara et al. 2003). Solar UVR is considered to be a major controlling factor for the abundance of mycosporine-like amino acids (MAAs) throughout the year (Llewellyn \& Harbour 2003). The downwelling solar irradiance of UVR ranges from $45 \mu \mathrm{W} \mathrm{cm}{ }^{-2}$ in the summer and $25 \mu \mathrm{W} \mathrm{cm}^{-2}$ in the winter in the western mid-North Pacific (Kuwahara et al. 2015). However, both the quantity and quality of UVR are al-

*Corresponding author: Satoru Taguchi; E-mail, satoru.sio@gmail.com tered when UVR penetrates into surface seawater (Kirk 1994, Hargreaves 2003). Consequently, the attenuation of UVR at a given wavelength should be partly affected by the concentrations of MAAs in the water column. In the water column, the attenuation of UVR is primarily regulated by dissolved organic matter (DOM) and particulate matter (PM). Dissolved MAAs are included in DOM, and the cellular MAAs of phytoplankton are included in PM. The attenuation of PAR is primarily regulated by the cellular pigment contents of phytoplankton in the surface mixed layer (Kirk 1994). Dissolved MAAs are an exudate of DOM released from phytoplankton (Vernet \& Whitehead 1996). The cellular MAAs are primarily synthesized de novo via the shikimate pathway (Shick \& Dunlap 2002). Phytoplankton intercellular MAAs are also partially responsible for regulating the attenuation of UVR in the surface mixed layers. The origin of MAAs in coastal waters is primarily from cyanobacteria (Sinha et al. 2001), micro- 
algae (Jeffrey et al. 1999), and red algae (e.g. Takano et al. 1979, Tsujino et al. 1980). The accumulation of MAAs in algal cells might enhance UVR attenuation within the cell, primarily between 310 and $340 \mathrm{~nm}$, thus providing a UVR shield for DNA (Buma et al. 1995). Although the short wavelengths of UVR, particularly 280-315 nm (UVB), are more responsible than the long wavelengths of UVR, such as 315-400 nm (UVA), for DNA damage in cells (Helbling et al. 2001), UVB is attenuated more rapidly than UVA in surface mixed layers in coastal waters at temperate latitudes (Kuwahara et al. 2015). Different effects of UVR can be expected in the surface mixed layer depending on the wavelength because the shorter wavelengths cause severe detrimental effects.

A high biomass of microalgae is typically observed during the warm season at temperate latitudes. During the period of high biomass, the concentration of MAAs in surface waters is also expected to increase, reflecting the high abundance of dinoflagellates and diatoms (Llewellyn \& Harbour 2003). Dinoflagellates and diatoms are the most active taxonomic groups for the synthesis of MAAs in the surface mixed layers of coastal waters (Jeffrey et al. 1999). UVR-protective MAAs have been observed in twenty forms in marine environments (Llewellyn \& Airs 2010). Although species-specific MAAs can be expected in the sea, mycosporine-glycine, shinorine, palythine, porphyra334 , palythene, and palythenic acid are typically considered to be the dominant MAAs (Llewellyn \& Airs 2010). The first four MAAs are also common in seven toxic dinoflagellates (Carreto et al. 2001). The effects of UVR on the synthesis of primary MAAs, such as mycosporine-glycine, shinorine, and porphyra-334 are positive, but not necessarily positive on the synthesis of secondary MAAs, such as palythine (Shick 2004). MAAs are synthesized under environmentally stressful conditions, such as high UVR. Not only is an increase in solar UVR expected during the summer in coastal waters, but a high UVR component of total radiation (PAR+UVR) is also expected (Ichikawa \& Taguchi 2001, Sugawara et al. 2003). The period of high UVR levels typically coincides with high temperature and low nutrient availability in temperate coastal waters. The concentration of MAAs might increase when elevated temperatures are combined with increased UV exposure (Shick \& Dunlop 2002). Low nitrogen availability under exposure to UVB has been reported to depress the synthesis of cellular MAAs in diatoms (Lesser et al. 1994), dinoflagellates (Litchman et al. 2002) and macroalgae (Korbee et al. 2005).

MAA concentrations are expected to be high during warm periods and low during cool periods, as indicated by the absorption of phytoplankton MAAs in the UV range in the ocean (Morrison \& Nelson 2004). This prediction likely reflects the linear relationship between the Chl $a$ biomass, an indicator of the phytoplankton biomass, and the concentration of MAAs in natural assemblages of phytoplankton (Carreto \& Carignan 2011). The objectives of the present study were two-fold: to determine the seasonal cycle of phytoplankton MAAs in temperate coastal waters with respect to the Chl $a$ biomass and the stability-reproducibility of the seasonal cycle of phytoplankton MAAs over six years in the western mid-North Pacific, and to determine UVR regulation by phytoplankton MAAs in the same region.

\section{Materials and Methods}

\section{Sampling}

Surface water was collected using a bucket at St. M, located at $35^{\circ} 09^{\prime} \mathrm{N}$ and $139^{\circ} 10^{\prime} \mathrm{E}$ off Manazuru Harbour, Sagami Bay, in central Japan (Fig. 1). Monthly cruises were conducted onboard the R.V. Tachibana of Yokohama National University during the periods from May 2004 to January 2007 and May 2011 to May 2012. The surface water was pre-screened through a $183-\mu \mathrm{m}$ mesh plankton net cloth and stored in carboys in a dark cold room at $4^{\circ} \mathrm{C}$. As soon as the samples were returned to the laboratory, the subsamples were filtered onto $25-\mathrm{mm}$ glass fiber filters (GF/F, Whatman, Dallas, USA) to analyze the Chl $a$ concentrations and 47-mm Whatman glass fiber filters $(\mathrm{GF} / \mathrm{F})$ for the analysis of MAAs. The analyses of Chl $a$ and MAA concentrations were conducted within three months after sampling. The filtrate was passed through Millipore membrane filters (Milex HA, 0.2- $\mu \mathrm{m}$ pore size, Whatman, Dallas, USA) for the analysis of nutrients. All filtrate samples were stored in vials below $-20^{\circ} \mathrm{C}$ under dark conditions.

\section{Optical measurements}

Solar irradiation was measured using a PUV-500 submersible radiometer and a PUV-510 surface radiometer (Biospherical Instruments Inc., USA), which provided measurements of cosine-corrected downwelling irradiance at St. M (Fig. 1). The instruments were designed to measure absolute UVR irradiance values with $10-\mathrm{nm}$ bands centered at 320 and $340 \mathrm{~nm}$. The mean surface irradiance just under the surface $(-0)$ was determined from the data collected during the underwater profile measurements. Vertical profiles of temperature and salinity were determined using a factory-calibrated conductivity-tempera-

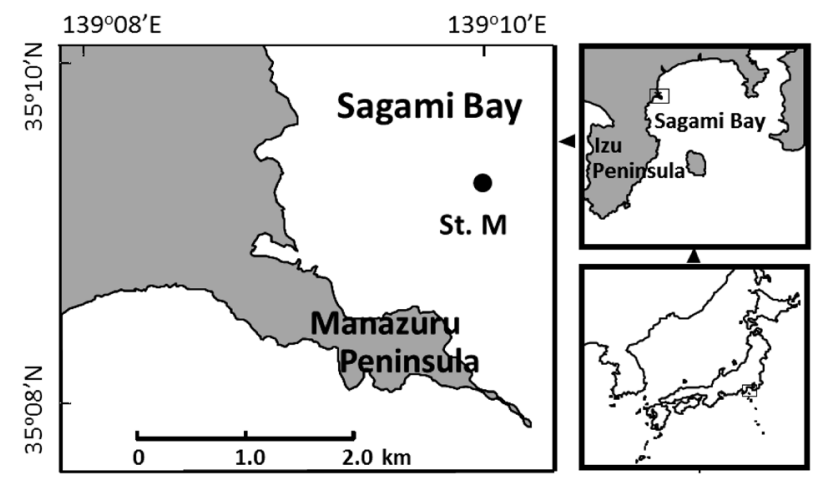

Fig. 1. Location of sampling station M in Sagami Bay, Japan. 
ture-depth sensor (JFE Advantech, ASTD100, Tokyo, Japan). Water density was estimated as sigma-t $\left(\sigma_{\mathrm{t}}, \mathrm{kg} \mathrm{m}^{-3}\right)$, and the surface mixed layer depth was determined based on a threshold value $\left(0.15 \mathrm{~kg} \mathrm{~m}^{-3}\right)$ larger than the average of the first $5 \mathrm{~m}$.

Irradiance profiles in the surface mixed layer (down to $40 \mathrm{~m}$ depth at $0.5 \mathrm{~m}$ per second) were obtained to determine the attenuation of UVR. The data were collected at 1 -sec intervals during the profiling. The measured irradiance profiles of the down-cast were recorded. All surface and profile casts were conducted within $3 \mathrm{~h}$ of solar noon, during which special attention was paid to the shadow of the ship. Dark corrections, according to Biospherical Instruments' protocols, were conducted prior to every profile. The sub-surface radiometer was consistently lowered into the water prior to measurements to minimize temperature effects. The current drag and tilt of the submersible sensor was maintained at a minimum during the study. Special attention was also paid to the rate at which the radiometer was lowered for each profile.

\section{Diffuse attenuation coefficients}

The data were cleaned to remove data points either outside the detection limit of the radiometer sensors or near the surface. Diffusive attenuation coefficients $\left(K_{\mathrm{d}}\right)$ for the downwelling irradiance at each wavelength were subsequently determined from the slope of the linear regression of the natural logarithm of downwelling irradiance at each respective wavelength $(\lambda)$ against the depth, assuming that solar irradiance reduced exponentially,

$$
E_{\mathrm{d}}=E_{\mathrm{d}}(-0) e^{-K_{\mathrm{d}} \cdot Z}
$$

where $E_{\mathrm{d}}$ is the downwelling irradiance at depth $\mathrm{Z}$ and $E_{\mathrm{d}}$ $(-0)$ is the downwelling irradiance just below the surface.

\section{Analysis}

\section{NUTRIENTS}

Concentrations of nitrate, phosphate, and silicate were determined using a Bran+Luebbe Autoanalyzer model AACS II according to Parsons et al. (1984).

\section{CHLOROPHYLL PIGMENTS}

Cellular material on the $25-\mathrm{mm}$ Whatman GF/F glass fiber filters was extracted in opaque vials using N,Ndimethylformamide for $24 \mathrm{~h}$ at $4^{\circ} \mathrm{C}$ (Suzuki \& Ishimaru 1990). The chlorophyll pigments were analyzed using a Turner Design Fluorometer model 10-AU according to Holm-Hansen et al. (1965) for the samples collected during the period from May 2004 to January 2006. For the samples collected during other periods, the extracts were sonicated for $10 \mathrm{~min}$ in an ice bath (International Electric Elutekku, Sine Sonic 150, Japan) and filtered through a membrane filter with a $0.2-\mu \mathrm{m}$ pore size (Millipore, Millex-GC, USA) for analysis on a high performance liquid chromatograph (HPLC). The filtrates were analyzed by HPLC (Beckman Coulter, 168 Diode Array Detector,
USA) with a C18 reverse-phase Ultrasphere $3 \mathrm{~mm}$ column, using a solvent gradient based on the modified method of Wright et al. (1997). The two instruments were intercalibrated to confirm the significant relationship.

\section{MICOSPORINE-LIKE AMINO ACIDS}

Cellular material on the $25-\mathrm{mm}$ Whatman $\mathrm{GF} / \mathrm{F}$ glass fiber filters was extracted in $1.5 \mathrm{~mL}$ of $20 \%(\mathrm{v} / \mathrm{v})$ methanol (HPLC grade, Wako, Japan) for at least $24 \mathrm{~h}$ at $37^{\circ} \mathrm{C}$ in the dark, after sonication of the harvested cell materials in an ice bath for $10 \mathrm{~min}$ at full strength. The methanolic extract was subsequently centrifuged at $10,000 \mathrm{rpm}$ for $5 \mathrm{~min}$. The supernatant $(1 \mathrm{~mL})$ was evaporated under reduced pressure and re-dissolved in $1 \mathrm{~mL}$ of $100 \%$ methanol. The extracts were vortexed and centrifuged, and the supernatant was carefully separated. The supernatant was evaporated until completely dry at $45^{\circ} \mathrm{C}$. The residue was re-dissolved in $100 \mu \mathrm{L}$ of MilliQ water and filtered through a $0.2-\mu \mathrm{m}$ membrane. Further analysis was performed by HPLC using a CAPCELL PAK C18 UG120 $5 \mu \mathrm{m}(250 \mathrm{~mm} \times 4.6 \mathrm{~mm}$ I.D., Shiseido, Tokyo, Japan) and Shiseido SG 120 5- $\mu \mathrm{m}$ guard column $(35 \mathrm{~mm} \times 4.6 \mathrm{~mm}$ I.D. Japan). During each run, the column was equilibrated with $100 \%$ solvent $\mathrm{A}$ [ $80 \%$ Milli-Q water and $20 \%$ (v/v) $0.5 \mathrm{M}$ ammonium acetate (Wako, Japan)] at a flow rate of $1 \mathrm{~mL} \mathrm{~min}^{-1}$, followed by $100 \%$ eluent B [75\% Milli-Q water, $25 \%$ (v/v) methanol and $0.2 \%$ acetic acid (Wako, Japan)] for $20 \mathrm{~min}$ at a room temperature. Peak absorbance was detected at 310 and $334 \mathrm{~nm}$. The MAA concentrations were calculated from the peak areas detected at $334 \mathrm{~nm}$ using the standard calibrated peak areas for individual MAAs. Common MAAs were identified based on the retention time, absorption spectra from 290 to $400 \mathrm{~nm}$, and co-chromatography with authentic standards, shinorine, palythine, and porphyra-334 obtained from the red algae Tichocarpus crinitus, Chondrus yendoi, and Porphyra yezoensis, respectively (Taira et al. 2004a). Mycosporine-glycine was obtained from cultures of the dinoflagellate Alexandrium tamarense (Taira et al. 2004b). The concentrations of MAAs were calculated using the following molar extinction coefficients: shinorine: $\varepsilon_{334}=44,700$ (Tsujino et al. 1980), palythine: $\varepsilon_{320}=36,200$ (Takano et al. 1978), porphyra-334: $\varepsilon_{334}=42,300$ (Takano et al. 1979), and mycosporine-glycine: $\varepsilon_{310}=28,100$ (Ito \& Hirata 1977). The ratios of MAAs to Chl $a$ were calculated based on the total MAAs in nM and Chla in $\mathrm{ng} \mathrm{L}^{-1}$.

\section{STATISTICAL ANALYSIS}

The means and standard deviations were calculated based on subsamples analyzed at least in triplicate. Significant differences between seasons were tested for using the Student's t-test for unpaired comparisons and a paired t-test, the Wilcoxon signed-rank test for paired comparisons, and the Kruskal-Wallis one-way analysis of variance on ranks for paired multiple comparisons using the SigmaPlot software program (System Software, version 11.0, San 

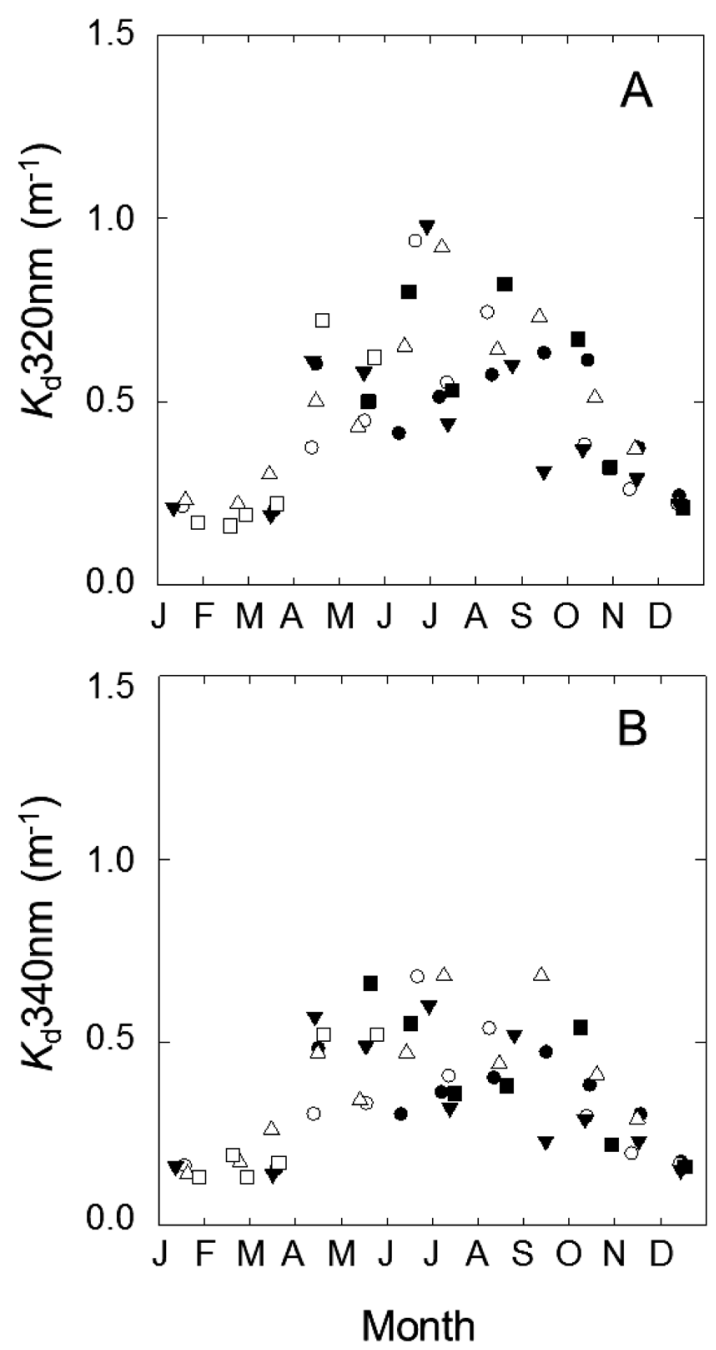

Fig. 2. Seasonal variation in the attenuation coefficients of UVR at $320 \mathrm{~nm}$ (A) and $340 \mathrm{~nm}$ (B). Symbols indicate the attenuation coefficients in 2004 (solid circles), 2005 (open circles), 2006 (reversed solid triangles), 2007 (open triangles), 2011 (solid squares) and 2012 (open squares).

Jose, USA).

\section{Results}

\section{Attenuation of UVR}

The intensity of UVR at 320 and $340 \mathrm{~nm}$ decreased rapidly with depth as it was rapidly attenuated, and an optical depth of $10 \%$ was typically shallower than the deepest extent of the surface mixed layer, ranging from approximately $12 \mathrm{~m}$ in the summer to $82 \mathrm{~m}$ in the winter. The attenuation of UVR, indexed based on the extinction coefficient of downwelling UVR $\left[K_{\mathrm{d}}(\lambda)\right]$, indicated a seasonal cycle with an increase in low water temperature months (February-July) and a decrease in high water temperature months (August-January), although the attenuation was variable among years (Fig. 2). The highest attenuation was
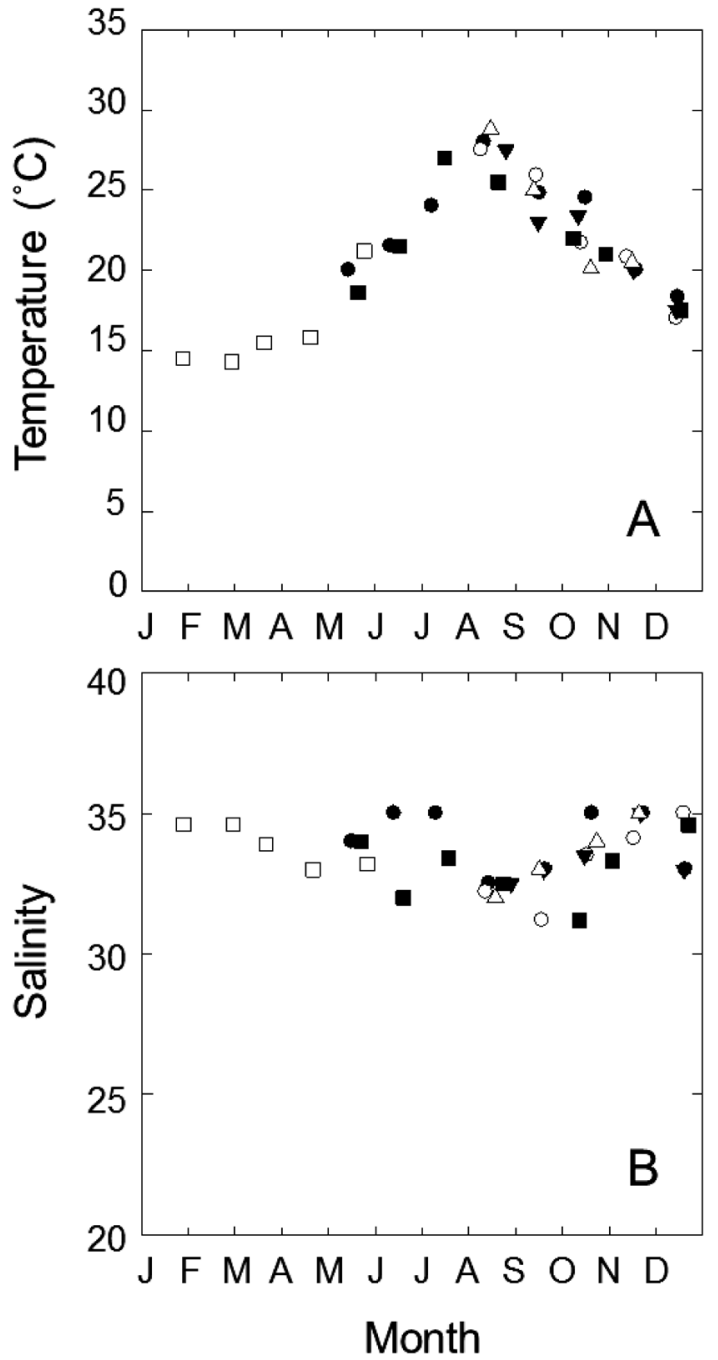

Fig. 3. Seasonal variations in the water temperature (A) and salinity (B). Symbols indicate the respective values in 2004 (solid circles), 2005 (open circles), 2006 (reversed solid triangles), 2007 (open triangles), 2011 (solid squares) and 2012 (open squares).

approximately $0.98 \mathrm{~m}^{-1}$ at $320 \mathrm{~nm}$ and $0.68 \mathrm{~m}^{-1}$ at $340 \mathrm{~nm}$, which was always observed in the high water temperature months. The lowest attenuation was approximately $0.16 \mathrm{~m}^{-1}$ at $320 \mathrm{~nm}$ and $0.13 \mathrm{~m}^{-1}$ at $340 \mathrm{~nm}$, observed during the low water temperature months.

\section{Temperature, salinity, and nutrients}

The surface temperature rapidly increased from April to a maximum of $28^{\circ} \mathrm{C}$ in July and gradually decreased to a minimum of $14^{\circ} \mathrm{C}$ in February (Fig. 3A). The surface salinity was low (ca. 31.5) at the highest temperature and high (ca. 35.5) at the lowest temperature (Fig. 3B). The high (February-July) and low (August-January) water temperate period were almost equivalent in length. In contrast with the harmonic cyclic changes in the surface temperature, the seasonal changes in nutrients were highly variable between years (Fig. 4A, B, and C). The highest concentrations of nitrate, phosphate, and silicate were $7.01 \mu \mathrm{M}$ 

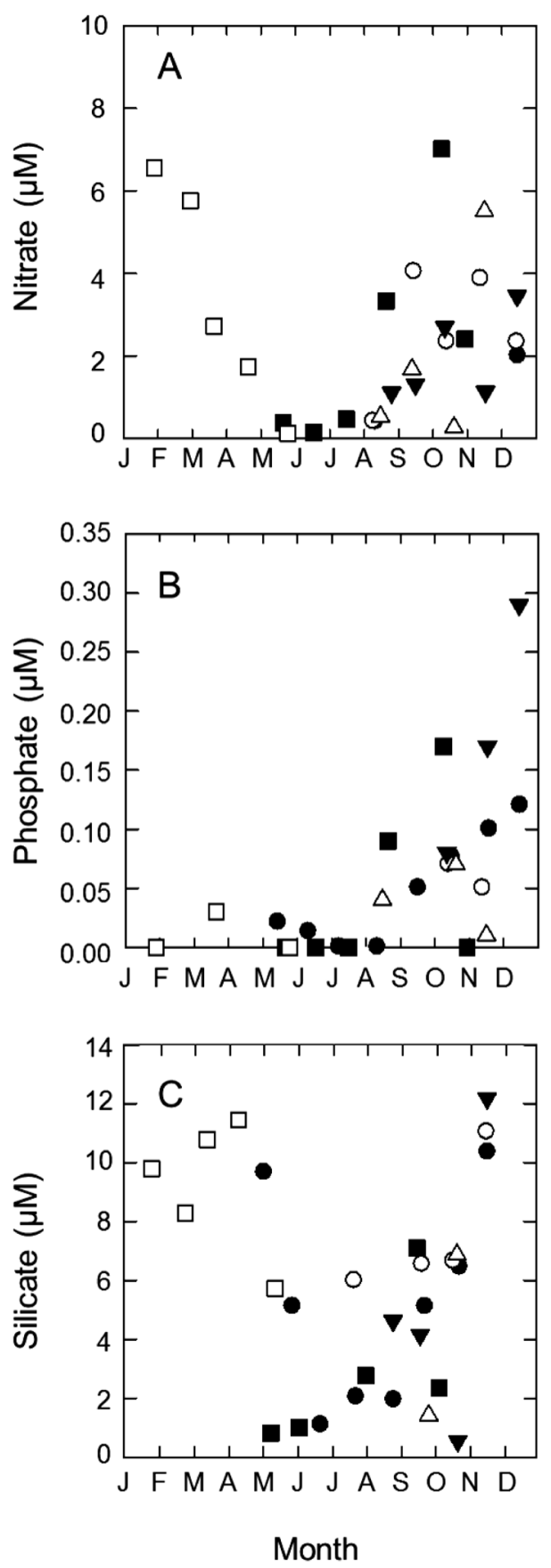

Fig. 4. Seasonal variations in the concentrations of nitrate, phosphate, and silicate. Symbols indicate the values in 2004 (solid circles), 2005 (open circles), 2006 (reversed solid triangles), 2007 (open triangles), 2011 (solid squares) and 2012 (open squares).

on October 8, 2011; $0.29 \mu \mathrm{M}$ on December 14, 2006; and $12.2 \mu \mathrm{M}$ on December 14, 2006, respectively, whereas the lowest concentrations were close to $0 \mu \mathrm{M}$ in June and July for all the measured nutrients. Macronutrients, such as nitrate, phosphate, and silicate, were almost completely exhausted during the peak periods of surface temperature. Both attenuations at 320 and $340 \mathrm{~nm}$ were only correlated positively with temperature and negatively with salinity, nitrate, and silicate $(p<0.05)$.

\section{Phytoplankton MAAs and $\mathrm{Chl} a$}

The concentrations of mycosporine-glycine, shinorine, palythine, and porphyra-334 indicated highly variable seasonal changes between years (Fig. 5). Mycosporine-glycine occurred at the highest $(130 \mathrm{nM})$ and lowest concentrations $(0.1 \mathrm{nM})$ in the summer and winter, respectively, but there was no stable seasonal trend, although concentrations of the other three MAAs exhibited a strong seasonal trend, increasing in high (February-July) and decreasing in low (August-January) water temperature periods. The concentrations of palythine ranged from $0.5 \mathrm{nM}$ in the winter to $90 \mathrm{nM}$ in the summer. The concentrations of shinorine ranged from $0.4 \mathrm{nM}$ in the winter to $70 \mathrm{nM}$ in the fall. The concentrations of porphyra-334 ranged from $0.1 \mathrm{nM}$ in the winter to $27 \mathrm{nM}$ in the summer. The concentrations of total MAAs were generally less than $20 \mathrm{nM}$ during the period from November to March, and values larger than $10 \mathrm{nM}$ were observed during the period from April to October (Fig. 6A). The Chl $a$ concentrations in these three periods were $0.4-6,0.4-8$, and $0.3-9 \mathrm{mg} \mathrm{Chl} a \mathrm{~m}^{-3}$, respectively (Fig. 6B). The total variation of phytoplankton MAAs was on the order of $10^{2}$, and the total variation in the Chl $a$ concentrations was also of the order of $10^{2}$. The total concentrations of MAAs (nM) were significantly correlated with the concentrations of $\mathrm{Chl} a\left(\mathrm{mg} \mathrm{m}^{-3}\right)$ (MAAs $=40 \mathrm{Chl} a+13, \mathrm{r}=0.39, p<0.05$ ). The highest relative proportion of mycosporine-glycine versus total MAA concentrations reached $90 \%$, while shinorine, palythine, and porphyra 334 reached $85 \%, 75 \%$, and $37 \%$, respectively. The respective relative abundances of MAAs were highly variable throughout the year (Fig. 7). A high relative abundance of mycosporine-glycine was observed during the warm period, while a high relative abundance of shinorine was observed during the cool period. All pairwise multiple comparison tests indicated significant relationships between MAAs/Chl $a, K_{\mathrm{d}}(320), K_{\mathrm{d}}(340)$, nitrate, and phosphate $(p<0.05)$.

\section{Discussion}

\section{MAAs}

There are more than 20 characterized MAAs with maximum absorption peaks ranging from 309 to $362 \mathrm{~nm}$ (Carreto \& Carignan 2011). In this study, four MAAs, specifically palythine, mycosporine-glycine, porphyra-334, and shinorine, were positively identified, although some unidentified peaks were also observed in the analyses. These peaks were not able to be assigned to specific MAAs, reflecting the uncertainty in peak positions and lack of standards available for laboratory studies. In coastal waters, two additional MAAs, palythene and palythenic acid, are commonly identified in addition to the four MAAs listed above (Llewellyn \& Airs 2010). The inclusion of these two 

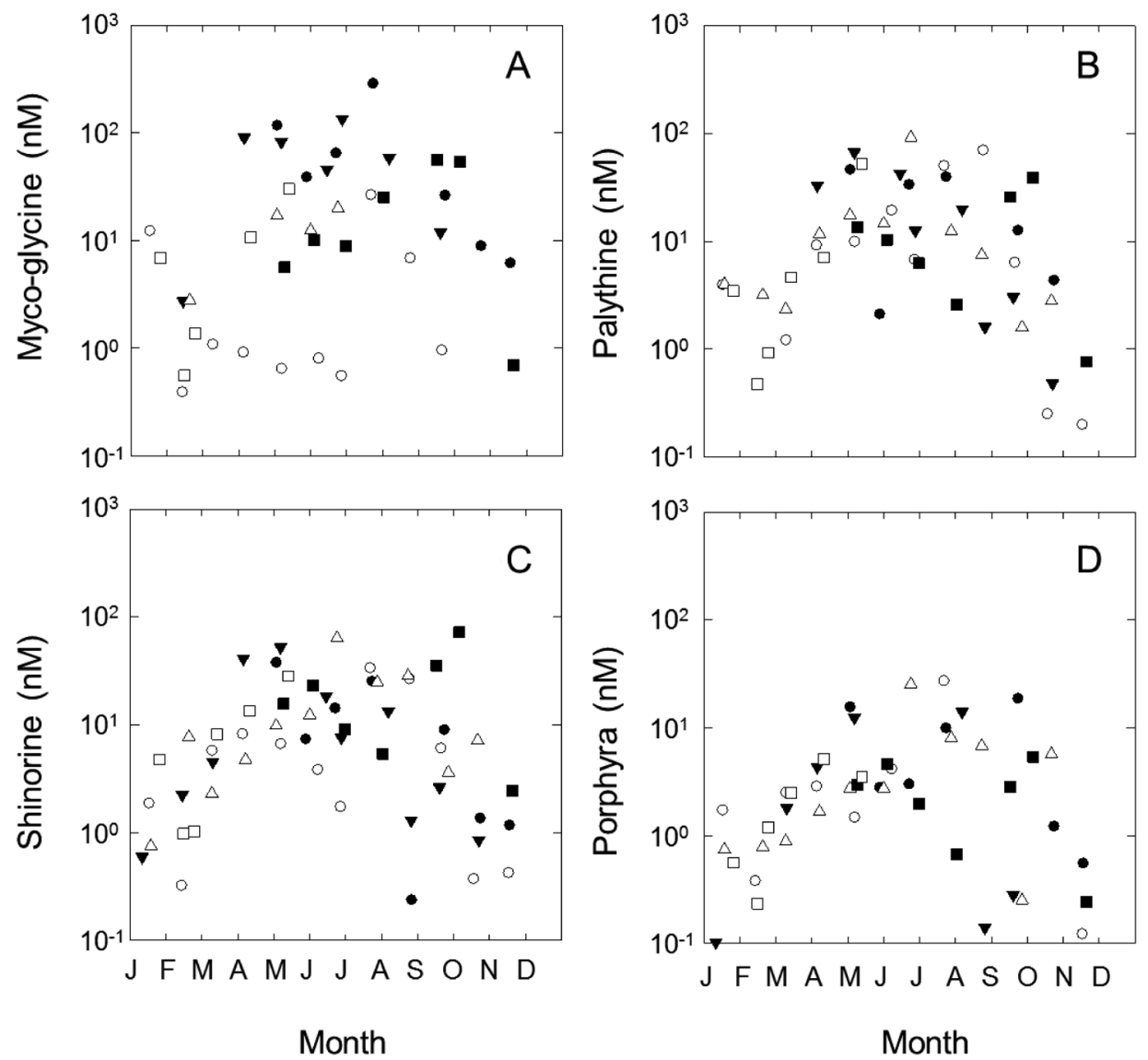

Fig. 5. Seasonal variations in the concentrations of mycosporine-glycine (A), palythine (B), shinorine (C), and porphyra-334 (D). Symbols indicate the values in 2004 (solid circles), 2005 (open circles), 2006 (reversed solid triangles), 2007 (open triangles), 2011 (solid squares) and 2012 (open squares).

MAAs in the present MAAs analysis would undoubtedly improve current understanding of the natural distribution and abundance of MAAs and UVR penetration in the sea, although the relative abundance of the two combined MAAs is expected to be $20 \%$ at most (Llewellyn \& Airs 2010).

\section{Seasonal cycle}

Seasonal cycles are common in biological systems, with amplitude and phase varying according to latitude (Demarcq et al. 2012). In most boreal waters, the biomass of phytoplankton, measured through the proxy of Chl $a$ concentration, increases during warm periods and decreases during cool periods. However, during the present study the Chl $a$ concentration fluctuated remarkably (10-fold at maximum) during the year. The seasonal patterns of Chl $a$ obtained in the present study were similar to those that have been previously observed in the region (Kuwahara et al. 2015). When Chl $a$ was present in the surface mixed waters, the presence of phytoplankton MAAs was also confirmed throughout the year, not only in the western North Pacific Ocean but also in other mid-latitude coastal waters (e.g., Llewellyn \& Mantoura 1997, Whitehead \& Vernet 2000, Riemer et al. 2007).
The amplitude and phase of the seasonal cycle of the total concentrations of MAAs has been reported to be associated with the attenuation of solar UVR (Zepp 2003). In addition, Llewellyn \& Harbour (2003) and Riemer et al. (2007) clearly confirmed a seasonal pattern, in that the maximum in total MAA concentrations occurred in summer in phytoplankton from the surface mixed layer of the English Channel and off Otago coast, New Zealand, respectively. The summer maximum in total MAA concentrations also coincided with the summer maximum in UV absorption by phytoplankton in a multiyear seasonal study by Morrison \& Nelson in Bermuda (2004).

The ratio of total MAAs, represented as the four major MAAs investigated in the present study, (i.e. mycosporine-glycine, shinorine, palythine, and porphyra 334) to the Chl $a$ concentration $\left(0.048 \pm 0.055 \mathrm{nM}\right.$ MAAs $\left.[\mathrm{ng} \mathrm{Chl} a]^{-1}\right)$ might provide some insight into the seasonal cycle of MAAs, as suggested by Carreto \& Carignan (2011). These four MAAs were present throughout the years examined in the present study, although the relative abundances were highly variable, presumably as a result of the variable community structure of the phytoplankton. The weak relationship between the total concentration of MAAs and Chl $a$ might suggest variable photo-adaptation and photo-accli- 

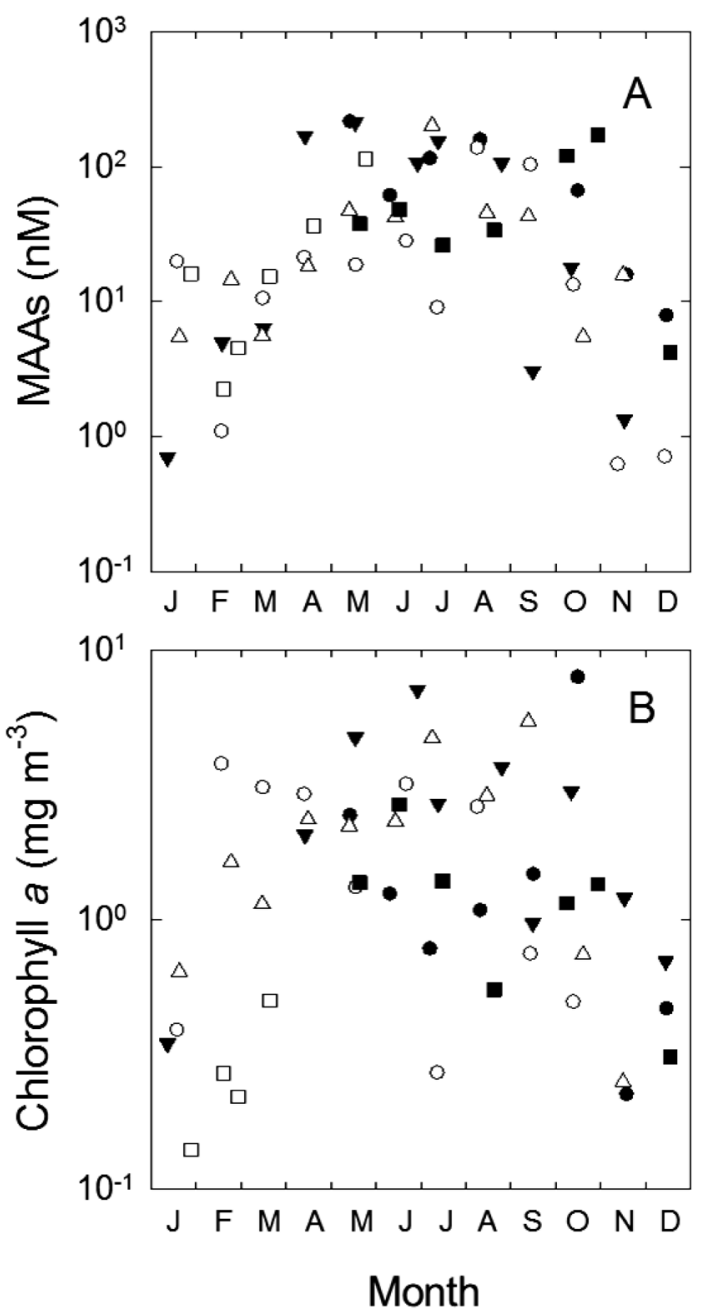

Fig. 6. Seasonal variations in the total MAA concentrations (A) and Chl $a$ concentrations (B). Symbols indicate the values in 2004 (solid circles), 2005 (open circles), 2006 (reversed solid triangles), 2007 (open triangles), 2011 (solid squares) and 2012 (open squares).

mation among the natural assemblages of phytoplankton in the region. Although the total pool of MAAs was the summation of the four MAAs in the present study, similar relationships were observed for UV absorption at $330 \mathrm{~nm}$ and Chl $a$ concentrations within a range from 0 to $10 \mathrm{mg} \mathrm{m}^{-3}$ in La Jolla Bay (Whitehead \& Vernet 2000), consistent with the results obtained in the present study. However, variations in the concentrations of MAAs only reflected approximately $15 \%$ of the variation of $\mathrm{Chl} a$ in the present study. Therefore, the interpretation of the relationship must be considered with caution. First, the slope of the relationship may be highly variable among natural assemblages of phytoplankton because individual MAAs are differently synthesized among species (Hannach \& Sigeleo 1998) and strains (Marshall \& Newman 2002). Secondly, the slope of the relationship could also vary between species, reflecting the variable biosynthesis of MAAs and resulting from nutrient availability rather than temperature or salin- ity. Ratios of MAAs/Chl $a$ were significantly correlated with concentrations of phosphate and nitrate $(p<0.05)$ in the present study. This suggests nutrient-dependency of MAAs/Chl $a$, as observed in diatoms (Lesser et al. 1994) and dinoflagellates (Litchman et al. 2002).

The ratios of MAAs to Chl $a(0.048 \pm 0.055 \mathrm{nM}$ MAAs [ng Chl $a]^{-1}$ ), which are analogous to the slope of the relationship as mentioned above, agreed well with those described in previous studies in natural assemblages of phytoplankton in the surface mixed layer. In natural assemblages of phytoplankton, the spring ratio of MAAs to Chl $a$ ranged from 0.00067 to $0.15 \mathrm{nM}$ MAAs (ng Chl $a)^{-1}$ in the coastal waters off California (Whitehead \& Vernet 2000), 0.0073 nM MAAs (ng Chl $a)^{-1}$ in the estuary of the Chesapeake Bay (Banaszak \& Neal 2001), from 0.0007 to $0.0027 \mathrm{nM}$ MAAs (ng Chl $a)^{-1}$ in the Southern Ocean (Moisan \& Mitchell 2001), and from 0.00011 to $0.016 \mathrm{nM}$ MAAs (ng Chl $a)^{-1}$ in the English Channel (Llewellyn \& Harbour 2003). A high ratio of $0.92 \mathrm{nM}$ MAAs (ng Chl $a)^{-1}$ was observed in the oligotrophic subtropical waters of the Brazil Current (Carreto \& Carignan 2011). The variability in the ratios obtained from natural assemblages of phytoplankton reflects two types of information concerning the species composition responsible for total MAA and $\mathrm{Chl} a$ concentrations as suggested by Bancroft et al. (2007). In diatom-dominated assemblages mycosporine-glycine has been reported to be consistently abundant, with porphyra-334 and shinorine occasionally being observed (Carreto \& Carignan 2011). Diatoms such as Thalassiosira spp. and Coscinodiscus spp. were abundant in the summer in this region, in terms of relative biovolume versus total phytoplankton cells (Mori \& Taguchi, unpublished data). Even in cultured populations of dinoflagellates, the ratio of MAAs to Chl $a$ can be highly variable, ranging from $0.019 \pm 0.001 \mathrm{pM}$ MAAs $(\mathrm{pg} \mathrm{Chl} a)^{-1}$ for Scrippsiella sweeneyae (Taira et al. 2004b) to $0.12 \mathrm{pM}$ MAAs ( $\mathrm{pg} \mathrm{Chl} a)^{-1}$ for Alexandria catenella (Carreto et al. 2001).

\section{MAA-dependent attenuation of UVR}

MAAs play a photoprotective role against UV exposure through a sunscreen effect (Neal et al. 1998). The seasonal cycle in the synthesis of MAAs is induced by environmental forces, primarily the quantity and quality of solar radiation (Llewellyn \& Harbour 2003). Downwelling solar irradiance at 320 and $340 \mathrm{~nm}$ ranged from 50 and $30 \mu \mathrm{W} \mathrm{cm}{ }^{-2}$ in the summer and 30 and $20 \mu \mathrm{W} \mathrm{cm}{ }^{-2}$ in the winter, respectively, at the sampling location in the present study (Kuwahara \& Taguchi 2015). To examine the effect of UVR on the concentrations of MAAs, determination of the attenuation coefficient of UVR at a given wavelength in the water column provides insight (e.g. Fig. 8), consistent with the findings of Hargreaves (2003). Kuwahara et al. (2015) reported a similar seasonal cycle of the attenuation coefficients to that seen in Figure 8. The attenuation coefficients at 320 and $340 \mathrm{~nm}$, measured during the present 

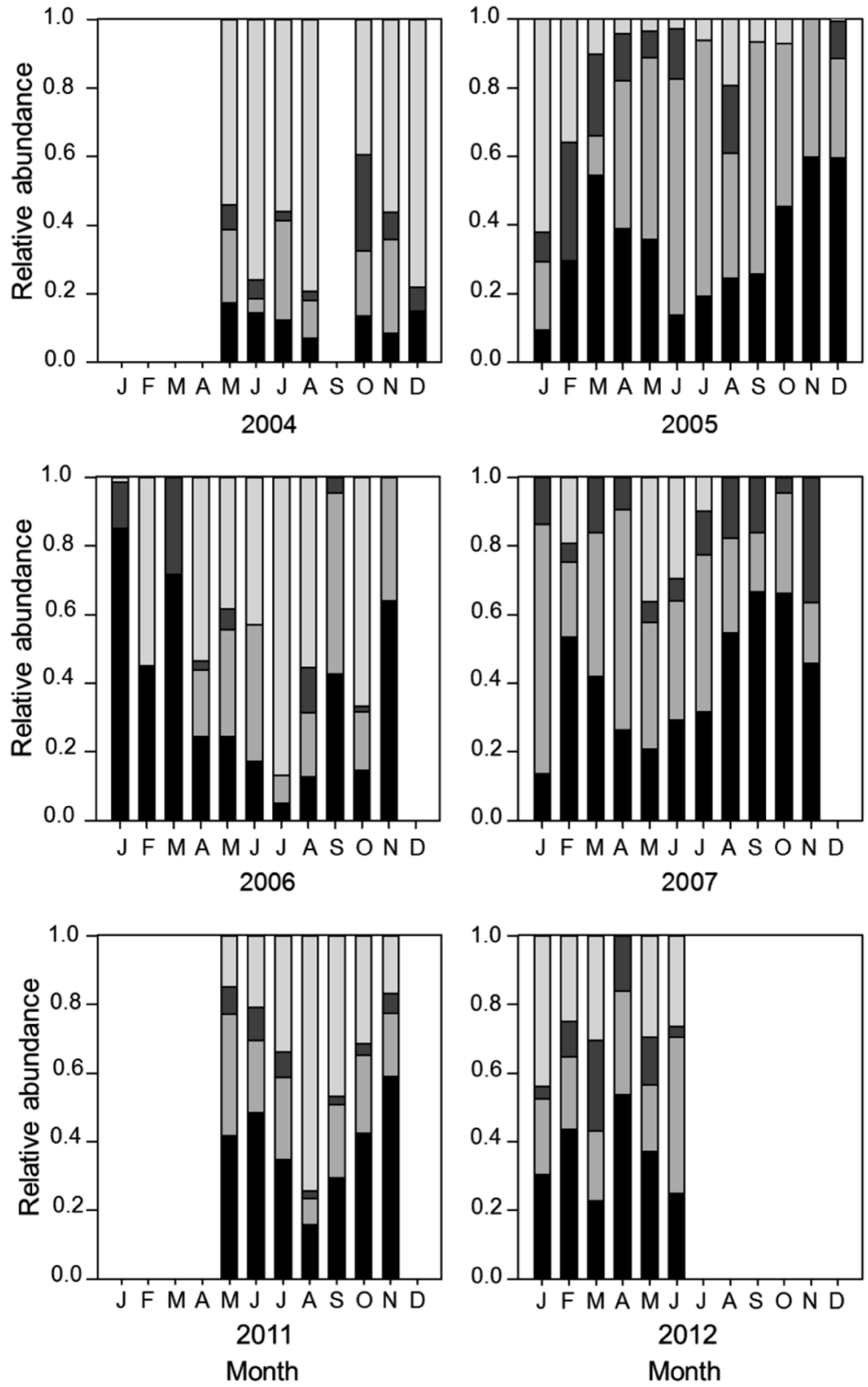

Fig. 7. Seasonal variations in the relative abundances of mycosporine-glycine (light grey), porphyra-334 (dark grey), palythine (medium grey), and shinorine (balck) in 2004 (A), 2005 (B), 2006 (C), 2007 (D), 2011 (E), and 2012 (F).

study, were within the range of the lowest values $\left(0.16 \mathrm{~m}^{-1}\right.$ and $0.10 \mathrm{~m}^{-1}$ ) yet reported (Boelen et al. 2001) to the highest reported values (obtained in tropical coastal water) of $1.45 \mathrm{~m}^{-1}$ and $0.99 \mathrm{~m}^{-1}$, respectively (Garza \& Suttle 1998). The total attenuation of UVR depends on attenuation due to water, DOM, detritus, and phytoplankton, following the equation:

$$
\begin{aligned}
K_{\mathrm{d}}(\mathrm{UVR})= & K_{\mathrm{d}}(\text { water })+K_{\mathrm{d}}(\mathrm{DOM})+K_{\mathrm{d}}(\text { detritus }) \\
& +K_{\mathrm{d}}(\text { phytoplankton })
\end{aligned}
$$

where $K_{\mathrm{d}}$ is downwelling attenuation $\left(\mathrm{m}^{-1}\right)$.

At the present sampling location, detritus and DOM from local river outflow immediately diffuse into the surrounding water upon entering Sagami Bay (Koyama et al.
2007), and these components have been found not to directly influence the seasonal attenuation of UVR or nutrient concentrations at St. M (Kuwahara et al. 2015). The attenuation of UVR is primarily controlled by DOM and MAA concentrations in ambient water and within phytoplankton cells (Moisan \& Mitchell 2001). This supposition is widely subscribed to, although few in situ measurements of the attenuation of UVR in relation to phytoplankton MAA concentrations have, in fact, been simultaneously conducted. Although UV-absorption at $330 \mathrm{~nm}$ was only nominally correlated with the particulate concentration of MAAs off the southern California coast (Whitehead $\&$ Vernet 2000), the significant relationships between the total concentrations of MAAs and the attenuation coef- 

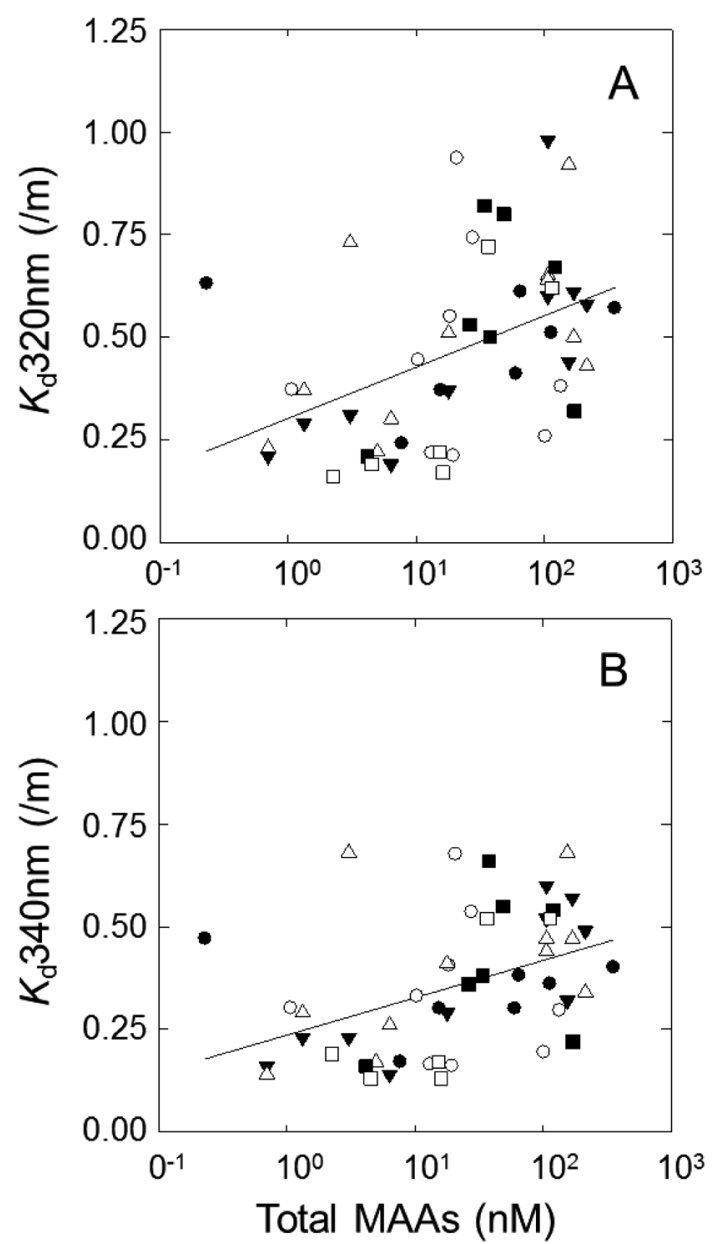

Fig. 8. Relationship between the total MAA concentrations and the attenuation coefficients at $320 \mathrm{~nm}$ (A) and $340 \mathrm{~nm}$ (B). Symbols indicate the values in 2004 (solid circles), 2005 (open circles), 2006 (reversed solid triangles), 2007 (open triangles), 2011 (solid squares) and 2012 (open squares).

ficients of UVA and UVB ( $p<0.01$, Fig. 8) suggest that phytoplankton MAAs absorbed UVA (ca. $340 \mathrm{~nm}$ ) in the present study. The absorption peaks of the four MAAs determined in the present study ranged from 320 to $334 \mathrm{~nm}$. The maximum absorption of UVR was reported to range from 313 to $335 \mathrm{~nm}$ for oceanic waters near Bermuda (Morrison \& Nelson 2004), although dissolved MAAs could also influence attenuation (Whitehead \& Vernet 2000).

\section{Ecological significance of MAAs}

The intracellular MAAs of microalgae contribute to the attenuation of UVR in the surface mixed layer year-round, in addition to the effects of dissolved MAAs. MAAs in microalgae are synthesized year-round, although the synthesis rate can be species-specific for any given MAA (Carreto \& Carignan 2011). In natural assemblages of phytoplankton, several species synthesize several groups of MAAs, and the correlation between the concentration of MAAs and Chl $a$ is not necessarily significant because synthesis of MAAs is controlled by environmental conditions (Carreto \& Carignan 2011). The quality and quantity of light and nutrients are critical environmental factors. The quality and quantity of UVR influences the synthesis of MAAs (Moisan \& Mitchell 2001), and a low availability of nutrients can also depress the synthesis of MAAs (Korbee et al. 2005). Attenuation of UVR might be greater in warmer periods because of high phytoplankton biomass and higher concentrations of intercellular MAAs. Primary MAAs, such as mycosporine-glycine, might be synthesized during the warm period, and secondary MAAs might be synthesized in subsequent periods (Carreto \& Carignan 2011). At shorter wavelengths of UVR, such as UV-B, increased attenuation of UVR occurs. In particular, the attenuation of UV-A $(315-400 \mathrm{~nm})$ by total MAAs might assist in recovery from photo-damage, as suggested by the high levels of accumulation of MAAs in natural assemblages of phytoplankton cells, and also by laboratory experiments (Carreto et al. 1990, Buma et al. 1995).

\section{Acknowledgements}

The present study was based on the five Bachelor's theses of $\mathrm{KC}, \mathrm{JH}, \mathrm{AT}, \mathrm{YY}$, and $\mathrm{KY}$ prepared during student research programs at Soka University. The authors would like to thank Dr. T. Kikuchi for assistance with sampling on the research vessel "Tachibana", Yokohama National University and A. Leong for assistance with finalizing figures. This work was partially supported by a grant from the National Institute of Environmental Science and special funds from Soka University. The authors would also like to thank anonymous reviewers for significant contributions to the revision of the present manuscript.

\section{References}

Bancroft BA, Baker NJ, Blaustein AR, (2007) Effects of UVB radiation on marine and freshwater organisms: a synthesis through meta analysis. Ecol Lett 10: 332-345.

Banaszak AT, Neal PJ (2001) Ultraviolet radiation sensitivity of photosynthesis in phytoplankton from an estuarine environment. Limnol Oceanogr 46: 592-603.

Boelen PM, Veldhuis JW, Buma AG (2001) Accumulation and removal of UVBR-induced DNA damage in marine tropical plankton subjected to mixed and simulated non-mixed conditions. Aqua Microb Ecol 24: 265-274.

Buma AG, Hannen JEJ, van Roza I, Veldius MJW, Gieskes WWG (1995) Monitoring ultraviolet-B induced DNA damage in individual diatom cell by immune-fluorescent thymine dimer detection. J Phycol 31: 314-321.

Carreto JJ, Carignan MO (2011) Mycosporine-like amino acids: relevant secondary metabolites. Chemical and ecological aspects. Mar Drugs 9: 387-446.

Carreto JJ, Carignan MO, Montoya NG (2001) Comparative studies on mycosporine-like amino acids, paralytic shellfish toxin and pigment profiles of the toxic dinoflagellates Alexan- 
drium tamarense, A. catebella and A. minutum. Mar Ecol Prog Ser 223: 49-60.

Carreto JJ, Carignan MO, Daleo G, De Marco SG (1990) Occurrence of mycosporine-like amino acids in the red tide dinoflagellate Alexandrium excavatum: UV-protective compounds? J Plankton Res 12: 909-921.

Demarcq H, Reygondeau G, Alvain S, Vantrepotte V (2012) Monitoring marine phytoplankton seasonality from space. Rem Sens Environ 117: 211-222.

Garza DR, Suttle CA (1998) The effect of cyanophages on the mortality of Synechococcus spp. and selection for UV resistant viral communities. Microb Ecol 36: 281-292.

Hannach G. and Sigleo D.S (1998) Photoinduction of UV-absorbing compounds in six species of marine phytoplankton. Mar Ecol Prog Ser 174: 207-222.

Hargreaves BR (2003) Water column optics and penetration of UVR. In, UV effects in aquatic organisms and ecosystems, (eds Hebling ER, Zagarese H). Royal Society of Chemistry, Cambridge, UK, pp. 291-327.

Helbling WE, Zagarese H (2003) UV Effects in Aquatic Organisms and Ecosystems. Royal Soc Chemistry, Cambridge, UK, pp. 575 .

Helbling WE, Buma AGJ, de Boer KM, Villafane VE (2001) In situ impact of solar ultraviolet radiation on photosynthesis and DNA in temperate marine phytoplankton. Mar Ecol Prog Ser 211: 43-49.

Holm-Hansen O, Lorenzen CJ, Holmes RN, Strickland JDH (1965) Fluorometric determination of chlorophyll. J Couns Perm Inter Expl Mer 30: 3-15.

Ichikawa T, Taguchi S (2001) Influence of UVB radiation on growth, carbon/chlorophyll $a$ ratio, and chlorophyll $a$-specific absorption coefficient of the marine diatom Thalassiosira weisflogii. Verh Inter Asso Theor Appl Limnol 27: 3343-3348.

Ito S, Hirata Y (1977) Isolation and structure of a mycosporine from the zoanthid Palythoa tuberculosa. Tetrahedron Lett 28: 2429-2430.

Japan Meteorological Agency (2015) Annual report on atmospheric and marine environment monitoring data. Japan Meteorological Agency.

Jeffrey SW, Mactavish HS, Dunlap WC, Vesk M, Groenewoud K (1999) Occurrence of UVA and UVB-absorbing compounds in 152 species (306 strains) of marine microalgae. Mar Ecol Prog Ser 189: 35-51.

Kirk JTO (1994) Light and Photosynthesis in Aquatic Ecosystems. Cambridge, U.K. Cambridge University Press, pp. 509.

Korbee N, Huovinen P, Figueroa FL, Aguilera J. Karsten U (2005) Availability of ammonium influences photosynthesis and the accumulation of mycosporine-like amino acids in two Porphyra species (Bangiales, Rhodophyta). Mar Biol 146: 645-654.

Koyama A, Kuwahara VS, Shibata A, Toda T, Kikuchi T, Taguchi S (2007) Seasonal variability in chromophoric dissolved organic matter in the Sakae River and Sagami Bay. Jpn Limno 8: 211-217.

Kuwahara VS, Taguchi S (2015) Estimating the diurnal cycle and daily insolation of ultraviolet and photosynthetically active radiation at the sea surface. Photochem Photobiol 91: 1103-1111.

Kuwahara VS, Nozaki S, Nakano J, Toda T, Kikuchi T, Taguchi
S (2015) 18-year variability of ultraviolet radiation penetration in the mid-latitude coastal waters of the western boundary Pacific. Estuar Coastal Shelf Sci 160: 1-9.

Lesser MP, Cullen JJ, Neale PJ (1994) Carbon uptake in a marine diatom during acute exposure to ultraviolet-B radiation-relative importance of damage and repair. J Phycol 30: 83-192.

Litchman E, Neal PJ, Benaszak AT (2002) Increased sensitivity to ultraviolet radiation in nitrogen-limited dinoflagellates: photoprotection and repair. Limnol Oceanogr 47: 86-94.

Llewellyn CA, Airs RL (2010) Distribution and abundance of MAAs in 33 species of microalgae across 13 classes. Mar Drugs 8: 1273-1291.

Llewellyn CA, Harbour DC (2003) A temporal study of mycosporine-like amino acids in surface water phytoplankton from the English Channel and correlation with solar irradiation. J Mar Biol Ass UK 83: 1-9.

Llewellyn CA, Mantoura RFC (1997) A UV absorbing compound in HPLC pigment chromatograms from Iceland Basin phytoplankton. Mar Ecol Prog Ser 158: 283-287.

Marshall JA, Newman S (2002) Differences in photoprotective pigment production between Japanese and Australian strains of Chattonnella marina (Raphidophyceae). J Exper Mar Biol Ecol 272: 13-27.

Moisan TA, Mitchel BG (2001) UV absorption by micosporinelike amino acids in Phaeocystis antarctica Karsten induced by phtosynthetically available radiation. Mar Biol 138: 217-227.

Morrison JR, Nelson NB (2004) Seasonal cycle of phytoplankton UV absorption at the Bermuda Atlantic Time-series Study (BATS) site. Limnol Oceanogr 49: 215-224.

Neal PJ, Banaszak A, Jarriel CR (1998) Ultraviolet sunscreens in Gymnodium sanguineum (Dinophyceae): mycosporine-like amino acids protect against inhibition of photosynthesis. J Phycol 34: 928-938.

Parsons TR, Maita Y, Lalli CM (1984) A Manual of Chemical and Biological Methods for Seawater Analysis. Oxford: Permagon Press, 173 pp.

Riemer U, Lamare BM, Peak BM (2007) Temporal concentrations of sunscreen compounds (mycosporine-like amino acids) in phytoplankton and in the New Zealand krill, Nyctiphanes australis GO. Sars. J Plankton Res 49: 215-224.

Shick JM (2004) The continuity and intensity of ultraviolet irradiation affect the kinetics of biosynthesis, accumulation, and conversion of mycosporine-like amino acids (MAAs) in the coral Stylophora pistillata. Limnol Oceanogr 49: 442-458.

Shick JM, Dunlop WC (2002) Mycosporine-like amino acids and related gadusols: biosynthesis, accumulation, and UV-protective functions in aquatic organisms. Annu Rev Physiol 64: 223-262.

Sinha RP, Klisch M, Helbling EW, Hader D-P (2001) Induction of mycosporine-like amino acids (MAAs) in cyanobacteria by solar ultraviolet-B radiation. J Photochem Photobiol B 60: 129-135.

Sugawara T, Hamasaki K, Toda T, Kikuchi T, Taguchi S (2003) Response of natural phytoplankton assemblages to solar ultraviolet radiation (UV-B) in the coastal water, Japan. Hydrobiol 493: 17-26.

Suzuki R, Ishimaru T (1990) An improved method for determination of phytoplankton chlorophyll using N, N-Dimethylfor- 
mamide. J Oceanogr Soc Japan 46: 190-194.

Taira, H, Aoki S, Yamanoha B, Taguchi S (2004a) Daily variation in cellular content of UV-absorbing compound mycosporine-like amino acids in the marine dinoflagellate Scrippseilla sweeneyae. J Photochem Photobiol B 75: 145-155.

Taira H, Goes J I, Gomes H, do R, Yabe K, Taguchi S (2004b) Photoinduction of mycosporine-like amino acids and cell volume increases by ultraviolet radiation in the marine dinoflagellate Scrippsiella sweeneyae. Plankton Biol Ecol 51: 82-94.

Takano S, Uemura D, Hirata Y (1978) Isolation and structure of a new amino acid, palythine, from the zoanthid Palythoa tuberculosa. Tetrahedron Lett 26: 2299-2300.

Takano S, Nakanishi A, Uemura D, Hirata Y (1979) Isolation and structure of a $334 \mathrm{~nm}$ UV-absorbing substance Porphyra-334 from the red algae Porphyra tenera Kjellman. Chem Lett 50: 419-420.

Tsujino I, Yabe K, Sekikawa I (1980) Isolation and structure of a new amino acid, shinorine, from the red algal Chondrus yendoi Yamada et Mikami. Bot Mag 23: 65-68. New Zealand Geophys Res Lett 22: 57-60.

Vernet M, Whitehead K (1996) Release of ultraviolet-absorbing compounds by the red tide dinoflagellate Ligulodinium polyedrum. Mar Biol 127: 35-44.

Whitehead K, Vernet M (2000) Influence of mycosporine-like amino acids (MAAs) on UV absorption by particulate and dissolved organic matter in La Jolla Bay. Limnol Oceanogr 45: 1788-1796.

Wright SW, Jeffery SW, Mantoura REC (1997) Evaluation of methods and solvents for pigment extraction. In: Phytoplankton Pigments in Oceanography: Guideline to Modern Methods (eds Jeffery SW, Mantoura RFC, Wright SW). Paris, UNESCO, pp. 261-262.

Zepp RG (2003) Solar UVR and aquartic cycles. In: UV Effects in Aquatic Organisms and Ecosystems (eds Hebling ER, Zagarese H). Royal Society of Chemistry, Cambridge, UK, pp. 291-327. 